\title{
Fermentação alcoólica na produção de etanol e os fatores determinantes do rendimento
}

A obtenção de etanol, realizada através de processos fermentativos está sujeita a diversas situações de estresse sofridas pelo micro-organismo e pode acarretar em redução da produção etanólica e prejuízo da eficiência industrial. Considerando que o Brasil é o primeiro produtor mundial de etanol combustível bem como de sua matéria prima, a cana de açúcar, o objetivo deste trabalho foi o estudo, através de revisões de literatura, das principais etapas do processo industrial e da bioquímica da fermentação, além de avaliar alguns fatores interferentes do processo de produção de etanol nas indústrias brasileiras. No Brasil, o método mais utilizado é o de batelada alimentada com reciclo de células, conhecido como Melle-Boinot que, além de produtivo expõem as leveduras a menor grau de estresse. Leveduras do gênero Saccharomyces são as mais empregadas pelas usinas brasileiras, sendo capazes de metabolizar a sacarose da cana de açúcar e produzir quando em meio anaeróbio, etanol e gás carbônico. Fatores como temperatura, pH, concentração alcoólica e presença de sulfito relacionam-se diretamente com o desempenho da levedura e sua viabilidade, que sendo prejudicada, pode favorecer contaminações. Problemas na viabilidade bem como as contaminações podem por sua vez acarretar baixa produtividade e diminuição da qualidade do produto final. Assim, o conhecimento das bases científicas que regem o processo fermentativo nas diferentes fases do processo industrial pode contribuir para a redução de problemas e aumento da produção.

Palavras-chave: Saccharomyces Cerevisiae; Fermentação Alcoólica; Contaminantes; Eficiência Industrial.

\section{Ethanol production by alcoholic fermentation and its yield- determining factors}

\begin{abstract}
In ethanol production via fermentation processes, fermentative microorganisms are subject to stress conditions, which can lead to low yields and loss of industrial efficiency. Considering that Brazil is the largest world producer of ethanol fuel and sugarcane, its raw material, this study presents a literature review of the main steps of industrial ethanol production, the biochemistry of alcoholic fermentation, and the yield-determining factors of ethanol production in Brazilian industries. In Brazil, cell-recycle batch fermentation, also known as the Melle-Boinot process, is the most common method of ethanol production; it results in good yields and exposes the yeasts to low levels of stress. Yeasts of the genus Saccharomyces are the main microorganisms employed in Brazilian industries, as they are able to metabolize sucrose from sugarcane and produce ethanol and carbon dioxide under anaerobic conditions. Factors such as temperature, $\mathrm{pH}$, alcohol concentration, and presence of sulfite are directly related to yeast performance and viability, which, if impaired, can favor contamination. Yeast viability problems or process contamination may result in low productivity and low-quality final products. Therefore, knowledge of the scientific basis of each step of alcoholic fermentation in industrial processes can contribute to reducing the occurrence of problems and increasing ethanol production.
\end{abstract}

Keywords: Saccharomyces Cerevisiae; Alcoholic Fermentation; Contaminants; Industrial Efficiency.

Topic: Biotecnologia

Reviewed anonymously in the process of blind peer
Received: $10 / 04 / 2018$

Approved: $24 / 05 / 2018$
Silvana Pedroso de Góes-Favoni

Faculdade de Tecnologia de Marília, Brasil http://lattes.cnpq.br/8795475459063406 silvanafavoni@hotmail.com

\section{Anne Caroline Cardoso Monteiro}

Faculdade de Tecnologia de Marília, Brasil

http://lattes.cnpq.br/0531638273415389 annemonteiro.fatec2013@outlook.com

\section{Claudia Dorta (iD}

Faculdade de Tecnologia de Marília, Brasil http://lattes.cnpq.br/1482612102710885 http://orcid.org/0000-0003-2760-4229 dortafatec@gmail.com

\author{
Mariele Gonçalves Crippa \\ Faculdade de Tecnologia de Marília, Brasil \\ http://lattes.cnpq.br/33472225634829530 \\ mariele_crippa@yahoo.com.br

\section{Elke Shigematsu (iD} \\ Faculdade de Tecnologia de Marília, Brasi \\ http://lattes.cnpq.br/0957209893546421 \\ http://orcid.org/0000-0002-6789-6732 \\ elkeds@hotmail.com
}

Referencing this:

GÓES-FAVONI, S. P.; MONTEIRO, A . C. C.; DORTA, C.; CRIPPA, M. G.; SHIGEMATSU, E.. Fermentação alcoólica na produção de etanol e os fatores determinantes do rendimento. Revista Ibero Americana de Ciências Ambientais, v.9, n.4, p.285-296, 2018. DOI: http://doi.org/10.6008/CBPC2179-6858.2018.004.0023 


\section{INTRODUÇÃO}

Em meados da década de 70 acontecimentos mundiais associados à emissão de substancias que comprometem o meio ambiente, pressões de preços e perspectivas de esgotamento das fontes não renováveis de combustíveis fósseis, levaram o Brasil a implementar o Programa Nacional do Álcool (PROALCOOL). Este fato introduziu definitivamente o etanol na matriz energética nacional, levando o país à posição de primeiro produtor mundial de etanol combustível (BRASIL, 2016; ANDRADE et al., 2009). Na safra 2015/2016, a produção brasileira de etanol foi estimada em 29,2 bilhões de litros garantindo ao país o perfil renovável de sua matriz energética (CONAB, 2015; MILANEZ et al., 2012).

A produção de etanol no Brasil tem como principal matéria prima à cana de açúcar (Saccharum officinarum L.), uma gramínea rica em sacarose, que através de um processo fermentativo pela ação da levedura Saccharomyces cerevisiae, tem seu dissacarídeo transformado em etanol $\left(\mathrm{C}_{2} \mathrm{H}_{6} \mathrm{O}\right)$ e gás carbônico $\left(\mathrm{CO}_{2}\right)$ (LIMA, 2012). A eficiência e viabilidade econômica deste processo biotecnológico são alcançadas a partir de três parâmetros fundamentais: a eficiência na extração da matéria prima açucarada, ou seja, do caldo de cana, a eficiência do micro-organismo na transformação da matéria prima em produto e um sistema industrial apropriado, com equipamentos e condições que favoreçam a ação do micro-organismo (MILANEZ et al., 2012; ANDRADE et al., 2009).

Conforme Chieppe Junior (2012), a levedura apresenta inúmeras reações enzimáticas em seu metabolismo celular e diversos fatores físicos, químicos e biológicos podem interferir negativamente na eficiência fermentativa, ou seja, em sua capacidade de converter os açúcares do mosto em etanol. Assim, o estudo de fatores como a temperatura, $\mathrm{pH}$, presença de nutrientes e inibidores, concentração de leveduras, contaminações microbianas entre outros são fundamentais na busca pela melhoria do rendimento alcoólico na prática industrial. Diante desse contexto, o objetivo do trabalho foi estudar os parâmetros e processos relacionados à eficiência da produção alcoólica em usinas sucroalcooleiras, sobretudo os fatores que interferem na etapa de fermentação realizada pela levedura Saccharomyces cerevisiae.

\section{DISCUSSÃO TEÓRICA}

\section{Matéria prima para produção de etanol}

No Brasil, a cana de açúcar constitui a principal matéria prima para a obtenção do etanol carburante. De acordo com Lima (2012) a cana de açúcar está entre as culturas agrícolas mais antigas e mais exploradas no Brasil, sendo o país o maior produtor mundial da planta, de açúcar e de etanol (BRASIL, 2016). Na composição da cana de açúcar destaca-se cerca de $80 \%$ de água e aproximadamente $20 \%$ de sólidos totais, principalmente açúcares sacarose (17\%), glicose $(0,4 \%)$, e frutose $(0,2 \%)$, além das cinzas (LIMA, 2012). Segundo Vieira (2012) tão importante quanto à produção de cana por hectare, é a qualidade da matéria prima, medida pelo teor de sacarose contida na planta e que determina o potencial de produção de açúcar por tonelada de cana. A qualidade da matéria prima em São Paulo e no Centro-Sul está entre 14 e 15,5\% de POL (sacarose aparente), o que equivale ao rendimento médio de 140 a $145 \mathrm{~kg}$ de açúcares totais 
recuperados (ATR) por tonelada de cana. Para o etanol, isso significa rendimento entre 80 e 85 litros por tonelada.

Nas usinas sucroalcooleiras, a produção do açúcar e de etanol segue as etapas de moagem da cana de açúcar, tratamento químico do caldo e filtração. Para obtenção do etanol, o caldo clarificado é aquecido a $115^{\circ} \mathrm{C}$ objetivando a concentração de sólidos solúveis em torno de $20^{\circ}$ Brix, além de sua esterilização. $O$ caldo aquecido é resfriado a $30^{\circ} \mathrm{C}$ em trocadores de calor e corrigido para compor o mosto (líquido açucarado fermentável) constituído pelo caldo clarificado adicionado de melaço (um sub produto obtido na produção de açúcar e conhecido também como mel final) e água para diluição dos sólidos solúveis, sendo geralmente utilizado $18^{\circ}$ Brix. O mosto corrigido será fermentado por leveduras, destilado e retificado para obtenção do etanol hidratado (com grau alcoólico entre 92,6 a 93,8\%) ou segue para a desidratação após a destilação para obter etanol anidro (teor alcoólico mínimo de 99,3\%) (CHIEPPE JUNIOR, 2012; SCHIAVONE, 2009).

\section{Processo fermentativo}

A fermentação alcoólica é um processo anaeróbico que ocorre pela transformação de açúcares em álcool etílico $\left(\mathrm{C}_{2} \mathrm{H}_{6} \mathrm{O}\right)$, e dióxido de carbono $\left(\mathrm{CO}_{2}\right)$, catalisado por enzimas. Este processo é executado principalmente por leveduras, em nível citoplasmático, tendo como objetivo a produção de energia, na forma de ATP, que será empregada nas funções fisiológicas e ainda para o crescimento e reprodução do microorganismo. O álcool etílico produzido constitui somente um subproduto de excreção desse processo, entretanto, age como inibidor de micro-organismos competidores.

Segundo Lima et al. (2001), a fermentação alcoólica se divide em três fases: preliminar, tumultuosa e complementar. A fase preliminar inicia-se, quando o substrato é acrescentado junto às células. Nesta fase, a multiplicação celular é intensa, e o açúcar consumido é usado na reprodução. Caracteriza-se por uma pequena elevação da temperatura e baixo desprendimento de $\mathrm{CO}_{2}$, cuja duração depende das características do sistema de fermentação, e pode ser reduzida quando se emprega elevada concentração de células ou pela adição de células em um meio nutricionalmente mais rico que o original.

Conforme Venturini Filho (2010), a fase tumultuosa se inicia com o desprendimento intenso de dióxido de carbono, que faz com que o mosto se agite como em ebulição, formando espuma. Durante esta fase há aumento da temperatura que é corrigida através de trocadores de calor. A duração desta fase é evidenciada pela diminuição do desprendimento de $\mathrm{CO}_{2}$.

$\mathrm{Na}$ fase complementar, o desprendimento de gás carbônico diminui sensivelmente e o líquido ascenta na dorna fermentativa, a temperatura abaixa e há redução abrupta no teor de açúcares do meio, completando o processo em torno de 8 horas durante a safra (PASCHOALINI et al., 2009). De acordo com Ferrari (2013), os processos fermentativos são classificados conforme a maneira que o substrato é adicionado às dornas de fermentação e o produto obtido é retirado. Para a obtenção de etanol, existem três tipos básicos: processo em batelada ou descontínuo, batelada alimentada, e o processo contínuo, sendo a batelada alimentada com reciclo de células (método Melle-Boinot), o processo mais utilizado nas destilarias brasileiras. 
No processo Melle-Boinot em que se mistura o mosto ao fermento conforme a dorna vai sendo abastecida, constitui um método produtivo e que expõe as leveduras a menores riscos de se tornarem inativas por repressão catabólica (PACHECO, 2010). Neste método ocorre o reaproveitamento de células de leveduras provenientes de uma fermentação anterior. No processo Melle-Boinot as células são separadas do vinho por centrifugação, saindo de um lado o leite de levedura composto pelas células e de outro o vinho delevedurado. Após a separação das células, estas são tratadas com ácido sulfúrico comercial até obtenção de $\mathrm{pH}$ entre 2,5 a 3,0, o que leva em torno de 3 horas para ocorrer, cuja finalidade é o controle da contaminação bacteriana. Além deste tratamento ácido, água é adicionada às células com o propósito de reduzir o teor alcoólico do meio, uma vez que o álcool constitui um importante fator estressante para a levedura. Nutrientes também são adicionados para suprir as necessidades metabólicas dos microorganismos e a homogeneização é feita com agitação. Toda esta etapa ocorre em dornas menores denominadas dornas de tratamento e uma vez tratado o inóculo este é reenviado à dorna de fermentação para a próxima batelada (VENTURINI FILHO, 2010). Cerca de 90\% das leveduras são reaproveitadas de uma batelada para outra e o reciclo de células ocorre durante toda a safra.

Normalmente a multiplicação do fermento é realizada no início da safra até que se atinja a concentração ideal de células para a condução do processo. Nesta etapa aeróbia a oxigenação normalmente é realizada com ar comprimido e sob agitação, em caldo de cana com sólidos solúveis entre 6 a $10^{\circ}$ Brix. Para favorecer a multiplicação rápida do fermento, sulfato de amônio, sulfato de magnésio, potássio, zinco, fósforo, entre outros são adicionados. Durante a safra o monitoramento desta concentração e viabilidade celular é realizado, e quando necessário às células são multiplicadas para garantir o percentual de células viáveis, pois mortes por envelhecimento e perdas de células durante o processo são comuns (CHIEPPE JUNIOR, 2012). Conforme Pacheco (2010), a concentração inicial do inóculo é de $10^{6}$ a $10^{7}$ células $/ \mathrm{mL}$ de mosto, e ao final da fermentação está concentração passa para $10^{8}$ células $/ \mathrm{mL}$ ou mais, sendo a concentração inicial de fermento um dos parâmetros fundamentais para a produtividade da fermentação.

De acordo com Venturini Filho (2010) alguns fatores levam o método Melle-Boinot em batelada alimentada a ser o mais empregado nas usinas sucroalcooleiras, pois acarreta maior rendimento em etanol com fermentações mais rápidas, necessita menor volume de dornas, isto é, um menor custo em instalação e garante grande pureza das fermentações diminuindo os riscos de contaminações, o que ocorre com frequência em fermentações contínuas e semi-contínuas.

\section{Levedura: agente da fermentação alcoólica}

Os micro-organismos do gênero Saccharomyces constituem os mais empregados pelas usinas sucroalcooleiras no Brasil. As leveduras são micro-organismos facultativos, isto é, realizam respiração pelo metabolismo aeróbico resultando na transformação do açúcar em $\mathrm{H}_{2} \mathrm{O}$ e $\mathrm{CO}_{2}$ e também o metabolismo anaeróbico quando na ausência do oxigênio, produzindo etanol $\left(\mathrm{C}_{2} \mathrm{H}_{6} \mathrm{O}\right)$ e dióxido de carbono $\left(\mathrm{CO}_{2}\right)$, além de subprodutos como ácidos orgânicos e glicerol (VENTURINI FILHO, 2010). 
Segundo Del Rio (2004), as leveduras devem apresentar certas características fundamentais para a eficiência do processo, como a velocidade de fermentação que é determinada pela quantidade de açúcar fermentado por uma quantidade de leveduras durante certo tempo. Quanto maior a velocidade de fermentação, maior a produtividade em fermentações mais rápidas, o que leva ao aumento da produção diária e reduz, consequentemente, o custo de produção e o risco de contaminação por micro-organismos prejudiciais. Outra característica desejada para as leveduras alcooleiras é a tolerância ao álcool em valores acima de $10 \%$ (p:v), uma vez que a baixa tolerância ao etanol limita o seu rendimento e produtividade durante a fermentação industrial. Além destes fatores, a resistência e dominância perante contaminantes e a estabilidade fisiológica para suportar oscilações no processo industrial também são fundamentais para estes micro-organismos.

Assim, a utilização de leveduras previamente isoladas de unidades brasileiras, vem sendo amplamente aplicada nas usinas sucroalcooleiras, dentre essas linhagens de S. cerevisiae isoladas estão a BG1 (Usina Barra Grande), CR-1(Usina Cresciumal), AS-1 (Usina Santa Adélia), CAT-1 (Usina Catanduva), PE-2 (Usina da Pedra) e CL (Usina Crealco). Estas linhagens são utilizadas como inoculo inicial para o começo da safra nas unidades das quais foram isoladas bem como para outras unidades (SOUZA, 2009).

A levedura é capaz de utilizar a sacarose presente na cana de açúcar quase que imediatamente, hidrolisando o dissacarídeo em glicose e frutose pela produção e ação da enzima sacarase ou invertase ( $\beta$ fructofuranosidase, EC. 3.2.1.26). A Saccharomyces cerevisiae dispõe de dois tipos de invertase, uma na forma extracelular ou periplasmática e outra intracelular, sendo que a extracelular apresenta- se como uma glicoproteína com cerca de 50\% de carboidratos (SALVATO, 2010).

A fermentação ocorre quando, após a glicólise, não é realizado o ciclo de Krebs, porque está via está bloqueada pela hipóxia (ausência de oxigênio). Então, as duas moléculas de piruvato sofrem descarboxilação pela ação da enzima piruvato descarboxilase, gerando duas moléculas de $\mathrm{CO}_{2}$ e duas de acetaldeído, que serão convertidas em duas moléculas de etanol pela ação da enzima álcool desidrogenase (MADIGAN et al., 2010).

De acordo com Monteiro (2016) deve ser levado em conta o relevante papel da glicose na regulação das opções metabólicas da levedura. A presença de glicose acima de $0,3 \%$ no mosto ocasiona um efeito repressor sobre os genes que codificam as enzimas da cadeia respiratória e estruturas mitocondriais, isto é, exerce uma repressão catabólica. Com isso, ocorre acumulo de biomoléculas em sua forma reduzida na qual o NADH gerado durante a glicólise é prevalentemente oxidado através da reação de conversão do piruvato em etanol, isto é, mesmo sob condições de aerobiose a fermentação predomina sobre a respiração. Com a repressão catabolica, ocorre aumento da taxa de fermentação e isto influencia negativamente os transportadores de açúcar para o interior da célula, resultando numa baixa produtividade de etanol. Este efeito regulatório do metabolismo da levedura é conhecido como efeito Crabtree.

Segundo Lima et al. (2001), a função primordial da levedura em metabolizar o açúcar é a geração de ATP, ou seja, uma forma de energia química instável que determinará a realização de diversas funções fisiológicas e biossínteses necessárias para manutenção do metabolismo da célula. $\mathrm{O}$ etanol e $\circ \mathrm{CO}_{2}$ 
resultantes constituem tão somente produtos de excreção, sem utilidade metabólica para a célula em anaerobiose. Entretanto, o etanol, bem como outros produtos de excreção (o glicerol e ácidos orgânicos), com redução da disponibilidade de glicose no meio, podem ser oxidados metabolicamente, gerando mais ATP e biomassa, mas apenas em condição de aerobiose, constituindo um comportamento metabólico conhecido com diáuxico.

Considerando que a levedura utiliza preferencialmente a sacarose, o cálculo estequiométrico mais utilizado como estimativa no processo produtivo, considera todo o açúcar que a levedura utilizará como sendo a glicose, assim $100 \mathrm{Kg}$ do açúcar produzirão 51,1 Kg de etanol e 48,9 Kg de $\mathrm{CO}_{2}$ (MARTINS, 2009). Entretanto, parte dos açúcares presentes no meio será consumida em reações paralelas necessárias para a síntese de etanol, formando outros produtos como glicerol e ácidos orgânicos, principalmente acético e succínico. Por estes motivos costuma-se observar rendimentos na fermentação alcoólica industrial em torno de 90\% (CANHA, 2009). Assim, a partir de $100 \mathrm{Kg}$ de glicose haverá uma produção real de aproximadamente $46,12 \mathrm{Kg}$ de etanol.

\section{Fatores que influenciam a fermentação alcoólica}

\section{Concentração etanólica}

Segundo Dorta (2006) a levedura Saccharomyces cerevisiae tem sua tolerância limitada perante o etanol, cuja concentração máxima que permite o crescimento é de $10 \%$ (p:v). O efeito inibidor do etanol está intimamente relacionado à temperatura da fermentação e a faixa de melhor resistência ao etanol para levedura é de 13 a $27^{\circ} \mathrm{C}$. Fora desta faixa de temperatura ocorre inibição do crescimento da levedura em função do álcool presente no meio.

Esta limitação quanto a presença de etanol no meio é verificada pela queda da viabilidade celular e pela redução do seu crescimento. $O$ etanol tem a capacidade de se instalar no meio da bicamada fosfolipídica mais precisamente na parte hidrofóbica, se alojando nos espaços que resultam das interações entre ácidos graxos insaturados e proteínas. Isto leva a um decréscimo na fluidez da membrana, pois restringi o movimento dos ácidos graxos na cadeia e promove um aumento da polaridade perturbando a troca livre das moléculas polares. O resultado é a alteração do posicionamento das proteínas na bicamada fosfolipídica, que afeta diretamente a capacidade da levedura em preservar o gradiente de concentração de compostos variados através da membrana citoplasmática, refletindo na inibição da taxa máxima de captação de glicose (MONTEIRO, 2016; BANAT et al., 1998).

pH

Sousa, Monteiro (2011) citam que as fermentações alcoólicas, podem desenvolver-se em ampla faixa de $\mathrm{pH}$, porém a faixa considerada ideal para o crescimento da levedura situa-se entre 4,0 e 5,0. Entretanto, a fermentação alcoólica industrial inicia-se com valores de pH mais baixos, entre 2,0 e 3,0 e finaliza com valores entre 3,5 a 4,0. Isto se dá porque fermentações alcoólicas quando são conduzidas em meios mais 
ácidos apresentam melhores resultados quanto ao rendimento em etanol, pelo fato de restringir o crescimento do fermento, e consequentemente a redução da produção de glicerol. Ao mesmo tempo, pH mais baixo reduz a contaminação bacteriana, e considerando que não há correção do pH durante o processo de fermentativo e tão somente durante o tratamento inicial do fermento, a condução da fermentação em pH em faixa abaixo do ótimo seria benéfica ao processo (LIMA et al., 2001; SOUSA et al., 2011). Porém, segundo Dorta (2006), em pH muito ácido (em torno de 2,0) os ácidos orgânicos que estão em seu estado não ionizado penetram na célula com mais facilidade causando inibição da levedura e pode também propiciar a seleção de bactérias resistentes e leveduras selvagens o que implica diretamente no rendimento etanólico.

\section{Temperatura}

O controle da temperatura consiste num fator importante durante o processo de fermentação alcoólica, pois para a produção de biomassa a temperatura ótima situa-se entre $25 \circ \mathrm{C}$ e 30 ㅇ C, caracterizandoas como micro-organismos mesófilos, enquanto para a produção alcoólica as temperaturas ótimas situamse na faixa mais ampla de 26 C a 35 ․ C. Chieppe Junior (2012) relaciona que valores de temperatura na faixa 260 $\mathrm{C}$ a 35 $\mathrm{C}$ causam enfraquecimento da levedura, ou seja, o crescimento é reduzido, além de ser propicio ao surgimento de contaminantes e ocasionar perdas do produto formado por evaporação. Já em temperaturas abaixo de 25 ㅇ C, a levedura apresenta menor atividade de crescimento e também de formação do produto.

No Brasil, o início da safra se dá no mês abril que condiz com o inverno, cuja temperatura é baixa, chegando perto de $14{ }^{\circ} \mathrm{C}$ a $15^{\circ} \mathrm{C}$, nas regiões Sul e Sudeste requerendo o aquecimento prévio do mosto para atingir a temperatura entre $28^{\circ} \mathrm{C}$ a $30^{\circ} \mathrm{C}$. No decorrer da safra, com o aumento da temperatura ambiente, esta medida se faz desnecessária. Como a fermentação alcoólica é um processo exotérmico, a temperatura do mosto pode exceder os limites admitidos para a fermentação, isso acarreta em fatores que afetam a atividade microbiana e por isso a temperatura durante a fermentação é controlada havendo resfriamento por trocadores de calor nas dornas fermentativas (SOUSA et al., 2011).

Embora as leveduras $S$. cerevisiae sejam mesófilas, não esporadicamente as temperaturas nas destilarias alcançam 38ㅇ C, dependendo das condições climáticas da região, pois o mosto é dispensado na dorna em temperatura ambiente. À medida que a temperatura se amplia, eleva-se a velocidade da fermentação, porém, conforme descrito acima, esta condição torna-se mais propicia à contaminação bacteriana, ao mesmo tempo em que a levedura fica mais sensível a toxidez do álcool, levando a formação de metabolitos secundários como o glicerol (LIMA et al., 2001).

\section{Contaminações bacterianas}

Segundo Viégas (2011) a cana de açúcar constitui um excelente meio de crescimento não apenas para as leveduras alcoólicas, mas também para bactérias contaminantes do processo, pois apresenta teor relevante de nutrientes, alta atividade de água e pH favorável, e sujidades vindas do campo ou mesmo 
provenientes do processo de obtenção do caldo da cana. Além disso, a má assepsia dos equipamentos intensifica ainda mais a contaminação bacteriana no processo de fermentação alcoólica.

O processo de infecção na fermentação alcoólica em níveis superiores à $10^{5}$ células $/ \mathrm{mL}$, pode ocasionar inúmeros danos ao processo industrial tais como: consumo de açúcar e redução da produção alcoólica, formação de goma refletindo no aumento da viscosidade do caldo e consequentemente ligado ao entupimento nas tubulações, danos aos equipamentos como centrifugas, peneiras e trocadores de calor elevando os custos em manutenção (CHIEPPE JUNIOR, 2012; NOBRE, 2005).

No decurso da infeç̧ão pode ocorrer a floculação do fermento, com diminuição da velocidade de fermentação, gerando perda de células de leveduras no fundo das dornas, o que dificulta o exercício das centrifugas, além do baixo rendimento alcoólico. Várias podem ser as causas para a floculação do fermento, todas relacionadas a contaminações: presença de gomas sintetizadas por bactérias, o próprio contato com bactérias indutoras da floculação e ainda pela presença de leveduras selvagens floculantes. Outro ponto de destaque para as contaminações é a presença de toxinas e ácidos orgânicos que ocasionam a inibição e a queda da viabilidade celular. Estes compostos excretados no meio pelos contaminantes, juntamente com todo o processo ocorrido leva a redução no rendimento da fermentação e interfere na eficiência da fermentação industrial (NOBRE, 2005; LUDWING et al., 2001)

Conforme Naves et al. (2010), no âmbito da fermentação e destilação industrial as bactérias lácticas são as predominantes iniciadoras de fermentações indesejáveis, particularmente as bactérias Gram-positivas do gênero Lactobacillus e Bacillus com destaque para L. fermentum, que predominam nas destilarias brasileiras. Os inconvenientes gerados pela floculação da levedura por contaminação bacteriana são intensificados pelo reciclo de células, que promove a condensação dos agentes de floculação juntamente com as leveduras e consequentemente decréscimo da produção de etanol (ALCARDE, 2001). Assim, o controle microbiano é extremamente relevante do ponto de vista da produção alcoólica com altos rendimentos.

Procedimentos como o tratamento com ácido sulfúrico realizado no creme de levedura, cujos custos são relativamente baixos, o uso de antibióticos tais como tetraciclina, cloranfenicol, penicilina e virginiamicina e a busca por novos métodos de controle devem ser estudados e otimizados, uma vez que podem prevenir a contaminação bacteriana (GOMES, 2009). Embora o tratamento com ácido sulfúrico seja amplamente empregado nas destilarias brasileiras, as leveduras são prejudicadas pelo ácido, que provoca extração de nutrientes como nitrogênio, fósforo e potássio, e ocasiona desgaste em sua parede celular prejudicando a produção de etanol (VIÉGAS, 2011; DORTA, 2006).

De acordo com Bertoletti (2008), a floculação gerada por espécies do gênero Lactobacillus estaria relativamente ligada com um mecanismo intracelular, na qual abrange os resíduos de aminoácidos indicados pela presença proteica do grupo indol do triptofano e o grupo hidroxil fenólico da tirosina da superfície celular da bactéria e carboidratos da parede celular da levedura. Além disto a relação intracelular necessita também da presença de íons $\mathrm{Ca}^{++}$, que atuam de modo direto na floculação. $\mathrm{O}$ cálcio exerce uma ponte de ligação entre os grupos negativos das fosfomananas que é um complexo de fosfato e mananas situada na 
parede celular da levedura e os receptores proteicos das células bacterianas. Níveis de pH acima de 3,0 contribui para que estas ligações ocorram, enquanto em pH inferiores a 3,0 e com quantidades elevadas de íons $\mathrm{H}^{+}$no meio, estes disputam as ligações com os íons $\mathrm{Ca}^{++}$. Por esse motivo as indústrias fazem uso da metodologia de reciclo de células (processo Melle-Boinoit) com a adição de ácido sulfúrico no tratamento do fermento para manter o $\mathrm{pH}$ baixo ocasionando o rompimento dessas pontes de ligação dos íons $\mathrm{Ca}^{++}$, apesar das injúrias que este tratamento pode provocar nas leveduras.

Outro procedimento adotado é o uso de antibióticos, porém o uso contínuo traz limitações como, por exemplo, a indução da resistência bacteriana a ação do antibiótico, além do custo elevado que este tratamento apresenta, considerando que seu uso deve ser contínuo na indústria (VIÉGAS, 2011; NAVES et al., 2010). Assim, conforme Viégas (2011) é constante a busca por novos compostos naturais bactericidas, que sejam mais eficientes que os atuais a um custo menor e que possam substituir antibióticos sintéticos, reduzindo então a resistência microbiana aos antibióticos empregados atualmente. Um exemplo disto é a própolis, substância resinosa produzida por abelhas e que tem se destacado no controle de bactérias contaminantes, sendo tão eficiente quanto à ampicilina em testes laboratoriais. Sua ação antimicrobiana está relacionada à presença de flavonoides, ácidos fenólicos, ésteres, aldeídos fenólicos e cetonas, cujo mecanismo da atividade antimicrobiana é complexo e atribuído ao sinergismo entre flavonoides, hidroxiácidos e sesquiterpenos (CAETANO et al., 2011).

Segundo Caetano e Madaleno (2011), outros biocidas naturais como o jambolão e o lúpulo estão sendo estudados pelo seu fator bactericida. Quanto ao jambolão, as folhas são ricas em taninos e saponinas e são citadas três hipótese para a ação antimicrobiana atribuída aos taninos. Uma delas é a de que os taninos inibem enzimas bacterianas e fúngicas e ou se complexam com os substratos dessas enzimas. A segunda hipótese inclui a ação dos taninos sobre as membranas celulares dos micro-organismos, modificando seu metabolismo, e a terceira fundamenta-se na complexação dos taninos com íons metálicos, diminuindo a disponibilidade de íons essenciais para o metabolismo microbiano. No que diz respeito ao lúpulo, os $\beta$-ácidos conhecidos como lupulonas possuem ação bactericida, agindo no transporte de metabólitos na membrana celular e alterando o pH intracelular. Sua pronunciada ação bacteriostática sobre bactérias Gram-positivas parece estar relacionada à interferência do grupo prenil, presente nas cadeias laterais dos $\beta$-ácidos, sobre a membrana plasmática das células, inibindo fortemente o seu crescimento. Porém, apesar de promissores, estes métodos alternativos ainda não são aplicados em nível industrial, sendo o procedimento quase que padrão nas destilarias brasileiras o uso de ácido sulfúrico no controle de contaminantes.

\section{Sulfito}

Conforme Dorta et. al (2006), o sulfito presente na fermentação alcoólica é proveniente da queima do enxofre elementar em fornos rotativos, no tratamento químico do caldo primário para retirada de impurezas solúveis, coloidais ou insolúveis com a finalidade de se fabricar o açúcar branco. Durante o processo de fabricação do açúcar gera-se um subproduto denominado melaço, também conhecido como 
Mel final. Um produto esgotado, que não serve para extrair mais açúcar por razões de ordens técnicoeconômicas.

De acordo com Steinle (2013) desde 1990, há um crescimento elevado da utilização do melaço na formulação do mosto juntamente com água e caldo de cana-de-açúcar para fermentação alcoólica. A utilização do melaço tem como finalidades principais a correção de sólidos solúveis do caldo e também por motivos econômicos, evitando assim perdas na eficiência da fabricação do açúcar. Amaral (2009), relata que o sulfito de sódio adicionado ao processo industrial é na faixa de 200 a 700 mg/L, gerando na maioria das vezes mostos com até $300 \mathrm{mg} / \mathrm{L}$ de dióxido de enxofre $\left(\mathrm{SO}_{2}\right)$.

Esta presença de sulfito no mosto ocasiona redução do rendimento alcoólico e diminuição da viabilidade das células das leveduras, sendo que os níveis de toxicidade podem ser maior ou menor perante as condições em que se encontram os níveis de $\mathrm{pH}$, a contaminação, assim como o teor alcoólico no decorrer do processo fermentativo (DORTA et. al, 2006). Conforme Favero et. al (2011), o sulfito age como um antimicrobiano tanto para bactérias como para as leveduras através de sua ligação a receptores celulares situados na parede celular do micro-organismo, ocasionando rompimento na membrana citoplasmática, inativação da replicação do DNA e da síntese de proteínas, inibição das reações catalisadas enzimaticamente vinculadas com a membrana citoplasmática, bem como, em reações individuais com os componentes de vias metabólicas. Um exemplo da ação antimicrobiana do sulfito está na inibição da cadeia enzimática encarregada pela produção de ATP, o que leva a diminuição da viabilidade celular.

Apesar de sua ação indesejada sobre as leveduras, Meneses (2008) cita que estudos relacionados com a toxidez do sulfito, mostraram que sua presença no meio fermentativo em até cerca de 100 ppm (partes por milhão) acarretaria benefícios ao processo de fermentação alcoólica, uma vez que diminui os custos de produção, pois exerce efeito inibitório no crescimento bacteriano, visto que a contaminação acarreta maiores danos ao rendimento alcoólico do que a presença de sulfito prejudicial às leveduras. Amaral (2009) relaciona que a concentração mínima inibitória (CMI), para o sulfito de sódio em pH 4,5 se encontra na faixa de $10-40 \mathrm{mg} / \mathrm{mL}$ para bactérias contaminantes do processo fermentativo, enquanto para a levedura os valores são de $5000 \mathrm{mg} / \mathrm{mL}$ em pH 4,5, o que justifica o uso do Mel na composição do mosto.

\section{CONCLUÇÕES}

Dentre os fatores que interferem no rendimento da fermentação alcoólica, o controle de pH, temperatura, presença de sulfito e teor alcoólico do meio é fundamental, pois relacionam-se diretamente ao desempenho e vitalidade da levedura Saccaromyces cerevisiae. Uma vez afetada a viabilidade celular, a tendência é o aumento do tempo de fermentação, o que acarreta custos mais elevados e propicia o aumento das contaminações bacterianas. As contaminações bacterianas por sua vez, em níveis acima de $10^{5}$ células $/ \mathrm{mL}$, provocam redução da produção alcoólica e aumento da acidez, o que leva à diminuição da qualidade do produto final. Assim, considerando a importância do etanol no mercado nacional, conhecer os fatores interferentes da fermentação alcoólica bem como medidas que melhorem a eficiência de sua obtenção deve ser cada vez mais estudados a fim de contribuir para melhorias do processo industrial. 


\section{REFERÊNCIAS}

ALCARDE, V. E.. Avaliação de parâmetros que afetam a floculação de leveduras e bactérias isoladas de processos industrias de fermentação alcoólica. 2001. Tese (Doutorado em Ciência em Tecnologia em Alimentos) - Universidade Estadual de Campinas, Campinas, 2001.

AMARAL, F. S.. Influencia conjunta do pH, temperatura e concentração de sulfito na fermentação alcoólica de mostos de sacarose, Dissertação (Mestrado) - Universidade Federal de Uberlândia, 2009.

ANDRADE, E. T.; CARVALHO, S. R. G.; SOUZA L. F.. Programa do proálcool e o etanol no Brasil, 2009. ENGEVISTA, v.11, n.2, p.127-136, 2009.

BANAT, I. M.; NIGAM, P.; SINGH, P.; MARCHANT, R.; McHALE, A. P.. Review: etanol production at elevated temperatures and alcohol concentration: Ppart $\mathrm{i}-$ Yeast in general. World Journal of Microbiologu and Biotechnology, v.14, n.6, p.809-821, 1998.

BERTOLETTI, A. C. D.. Ação biocida do Poliquilgerm ${ }^{\circledR}$ derivado do óleo de Ricinus communis L. (mamona) sobre bactérias contaminantes da fermentação etanólica. Dissertação (mestrado) - Universidade Estadual Paulista, Rio Claro, 2008.

BRASIL. Produção Brasileira de Cana de Açúcar, Açúcar e Etanol. Brasília: MAPA, 2016.

CAETANO, A. C. G.; MADALENO, L. L.. Controle de contaminantes bacterianos na fermentação alcoólica com a aplicação de biocidas naturais, 2011. Ciência \& Tecnologia, v.2, n.1, p.27-37, 2011.

CANHA, M. A.. Rendimento de fermentação, 2009. Monografia (Tecnologia) - Universidade Estadual de Maringá, Umuarama, 2009.

CHIEPPE JÚNIOR, J. B.. Tecnologia e fabricação do álcool: Rede e-Tec Brasil. Inhumas: IFG; Santa Maria: Universidade Federal de Santa Maria, 2012.

CONAB. Companhia Nacional de Abastecimento. Acompanhamento da safra brasileira de cana-de-açúcar: Safra 2015/2016, n.3 - terceiro levantamento. Brasília, 2015.

COSTA, V. M.. Perfil de metabólicos excretados por Lactobacillus isolados de processos industriais de produção de etanol, com ênfase nos isômeros óticos $D(-)$ e $L(+)$ do ácido lático. Dissertação (Mestrado em Ciência em Tecnologia em Alimentos) - Universidade de São Paulo, Piracicaba, 2006.

DEL RIO, D. T.. Biossorção de cádmio por leveduras Saccharomyces cerevisiae. Dissertação (Mestrado) Universidade de São Paulo, Piracicaba, 2004.

DORTA, C.; OLIVA-NETO, P.; ABREU-NETO, M. S.; NICOLAUJUNIOR, N.; NAGASHIMA, A. I.. Synergism among lactic acid, sulfite, $\mathrm{pH}$ and ethanol in alcoholic fermentation of Saccharomyces cerevisiae (PE-2 and M-26). World Journal of Microbiology ans Biotechnology, v.22, p.177-182, 2006.
FAVERO, D. M.; RIBEIRO, C. D. S. G.; AQUINO, A. D.. Sulfitos: importância na indústria alimentícia e seus possíveis malefícios à população. Segurança Alimentar e Nutricional, Campinas, v.18, n.1, p.11-20, 2011.

FERRARI, F. C. D. S.. Fatores operacionais e cinética do processo fermentativo para otimização da produção de etanol em escala industrial. Dissertação (mestrado) Universidade Estadual Paulista, Jaboticabal, 2013.

FORSYTHE, S. J.. Microbiologia da segurança alimentar. Porto Alegre: Artmed, 2002.

GOMES, F. S.. Antagonismo entre leveduras e bactérias láticas na fermentação alcoólica. Dissertação (Mestrado) Escola Superior de Agricultura 'Luiz de Queiroz', Piracicaba, 2009.

LIMA, L. R.; MARCONDES, A. A.. Álcool carburante: uma estratégia brasileira. 67 ed. UFPR, 2002.

LIMA, R. B.. Processo de clarificação do caldo de cana-deaçúcar aplicando elétrons acelerados. Dissertação (Mestrado) - Universidade de São Paulo, São Paulo, 2012.

LIMA, U. A.; AQUARONE, E.; BORZANI, W.; SCHMIDELL, W.. Biotecnologia industrial: Processos fermentativos e enzimáticos. São Paulo: Blucher, 2001.

LUDWING, K. M.; OLIVA-NETO, P.; ANGELIS, D. F.. Quantificação da floculação de $S$. cerevisiae por bactérias contaminantes da fermentação alcoólica. Ciência e Tecnologia de Alimentos, v.21, p.63-68, 2001.

MADIGAN, M. T.; MARTINHKO, J.; DUNLAP, P. V.; CLARK, D. P.. Microbiologia de brock. 12 ed. Porto Alegre: Artmed, 2010.

MARTINS, C. A. P.. Avaliação do efeito do inoculo e do perfil de alimentação do mosto na produção em escala piloto e industrial de etanol. Dissertação (Mestrado) - Universidade Federal de São Carlos, São Carlos, 2009.

MENESES, S. R. P. D.. Monitoramento de espécies químicas produzidas durante a fermentação alcoólica utilizando sistemas de analises em fluxo. Tese (Doutorado Química na Agricultura e no Ambiente) - Universidade de São Paulo, 2008.

MILANEZ, A. Y.; NYKO, D.; GARCIA, J. L. F.; REIS, B. L. S. F. S.. $O$ déficit de produção de etanol no Brasil entre $2012 \mathrm{e}$ 2015: determinantes, consequências e sugestões de política. BNDES Setorial, 2012.

MONTEIRO, B. M. D. S.. Produção de etanol combustível: efeito da suplementação nitrogenada na fermentação de mosto de caldo de cana com alta concentração de açúcar. Tese (doutorado) - Escola Superior de Agricultura 'Luiz de Queiroz', Piracicaba, 2016.

NAVES, R. F.; FERNANDES, F. S.; PINTO, O. G.; NAVES, P. L. F.. Contaminação microbiana nas etapas do processamento $\mathrm{e}$ sua influência no rendimento fermentativo em usinas 
alcooleiras. Enciclopédia Biosfera, Goiânia, v.6, n.11, p.1-16 2010.

NOBRE, T. P.. Viabilidade celular de Saccharomyces cerevisiae em associação com bactérias contaminantes da fermentação alcoólica. Dissertação (Mestrado em Ciência em Tecnologia em Alimentos) - Universidade de São Paulo, Piracicaba, 2005.

PACHECO, T. F.. Fermentação alcoólica com leveduras de características floculantes em reator tipo torre com escoamento ascendente. Dissertação (Mestrado) Universidade federal de Uberlândia, 2010.

PASCHOALINI, G.; ALCARDE, V.. Estudo do processo fermentativo de usina sucroalcooleira e proposta para sua otimização. Revista de Ciência \& Tecnologia, v.16, n.32, p.59-68, 2009.

SALVATO, F.. Fermentação de mosto industrial por linhagens de Saccharomyces cerevisiae com transportador de sacarose e sobre expressão de invertase interna: estudo comparativo com linhagens com alta e baixa atividade de invertase externa. Dissertação (Mestrado) Escola Superior de Agricultura Luiz de Queiroz, Piracicaba, 2010.

SANTOS, A. M. d. Estudo da influência da complementação de nutrientes no mosto sobre o processo de fermentação alcoólica em batelada. Dissertação (Mestrado em Química e Biotecnologia) - Universidade Federal de Alagoas, Maceió, 2008.
SILVA, A. F.. Caracterização genética de linhagens de Saccharomyces cerevisiae isolada de fermentações espontâneas de cachaças de alambique da Bahia. Dissertação (Graduação em Biotecnologia) - Universidade Estadual de Feira de Santana, Salvador, 2009.

SOUSA, J. L. U.; MONTEIRO, R. A. B.. Fatores interferentes na fermentação alcoólica para produção de etanol. FAZU em Revista, Uberaba, n.8, p.100-107,2011.

SOUZA, C. S.. Avaliação da produção de etanol em temperaturas elevadas por uma linhagem de $S$. cerevisiae. Tese (Doutorado em Biotecnologia) - Instituto Butantan, São Paulo, 2009.

STEINLE, L. A.. Fatores que interferem na fermentação alcoólica. Monografia (Graduação em Gestão do Setor Sucroenergético) - Universidade Federal de São Carlos centro de Ciências Agrárias, Sertãozinho, 2013.

VENTURINI FILHO, W. G.. Bebidas alcoólicas: Ciência e tecnologia. São Paulo: Blucher, 2010.

VIÉGAS, E. K. D.. Propriedade antibacteriana da própolis verde sobre bactérias contaminantes da fermentação etanólica. Dissertação (Mestrado em Ciência em Tecnologia em Alimentos) - Universidade de São Paulo, Piracicaba, 2011.

VIEIRA, M. C. A.. Setor Sucroalcooleiro Brasileiro: evolução e perspectivas. BNDS, 2012

A CBPC - Companhia Brasileira de Produção Científica (CNPJ: 11.221.422/0001-03) detém os direitos materiais desta publicação. Os direitos referem-se à publicação do trabalho em qualquer parte do mundo, incluindo os direitos às renovações, expansões e disseminações da contribuição, bem como outros direitos subsidiários. Todos os trabalhos publicados eletronicamente poderão posteriormente ser publicados em coletâneas impressas sob coordenação da Sustenere Publishing, da Companhia Brasileira de Produção Científica e seus parceiros autorizados. Os (as) autores (as) preservam os direitos autorais, mas não têm permissão para a publicação da contribuição em outro meio, impresso ou digital, em português ou em tradução. 